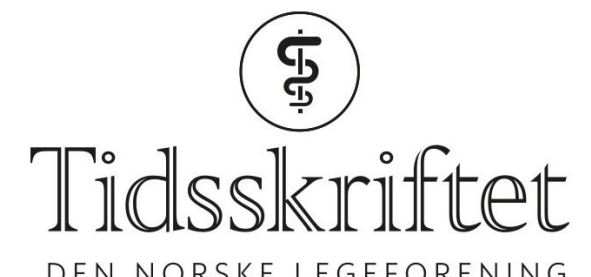

DEN NORSKE LEGEFORENING

\title{
Praksisperioder i medisinstudiet - bedre i Sverige?
}

LEGELIVET

VICTORIA SCHEI

E-post: victoria.schei.92@gmail.com

Victoria Schei er femteårs medisinstudent ved Universitetet i Bergen.

Som norsk legestudent i sykehuspraksis i Sverige blir jeg møtt med vennlighet og en godt planlagt praksis. Det er behagelig, men det er ikke poenget.

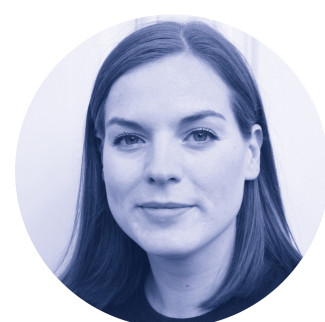

Foto: Anja Berntsen Wcrnes

Jeg sitter baklengs på Statens Järnvägars snabbtåg i retning Göteborg. Jeg funderer på hva en norsk femteårsstudent som har hatt sykehuspraksis i tre land, kan bidra med i legedebatten? Jeg bestemmer meg for å skrive om måten jeg har blitt møtt på som legestudent i et svensk sykehus.

Hadde de virkelig laget en individuell plan for meg?

Hvorfor er sykehuspraksis så interessant? Jo, praksisopplevelsen er viktig fordi det skjer noe med den fremtidige legen når han blir forlatt på morgenmøtet og ingen leger vil «ha student». Det skjer noe når du første praksisdag er prisgitt en lege som i seks timer gjør papirarbeid på skjermen og signaliserer at han ikke vil bli forstyrret. Det skjer noe med bildet av hva en lege skal være. Og det skjer noe med motivasjonen. Hvorfor møte opp i et hektisk fremmedartet miljø hvis ingen vil ha deg der og du ikke forstår noe? Mange norske studenter har slike erfaringer, viser undersøkelsen Til glede og besvcer - praksis $i$ høyere utdanning fra Nasjonalt organ for kvalitet i utdanningen (NOKUT). Praksis er et lotteri hvor det er tilfeldig om det går bra eller dårlig. «Én student kan oppleve praksis som 'noe av det beste ...', mens for en annen er praksis 'noe av det verste ...'’.

«Hvorfor skal du på utveksling til Sverige? Det er jo rett ved Norge. Det meste er sikkert helt likt. Og du har jo allerede vært på utveksling?» ble jeg spurt. Noe godt svar hadde jeg ikke da jeg manøvrerte den stappfulle gule fjellsekken inn på Bergensbanen og satte kursen østover en varm augustdag. Bortsett fra klisjéene om eventyret ved å oppsøke det ukjente, møte nye mennesker, se verden - disse lengslene som får oss til å forlate det trygge og nære til fordel 
for et velkomstbrev i innboksen og en tom studenthybel i en blokk i Göteborg.

Jeg er ikke bare ‘studenten’, en observatør til bry som dessverre må være her. Jeg er en del av teamet

Da jeg møtte opp i femte etasje på Kvinnokliniken på Sahlgrenska universitetssjukhuset på min første praksisdag, fikk jeg en håndskrevet lapp av en vennlig jordmor som ventet på meg:

Information till läkarkandidater, Reproduktionsavdelningen, 4. september

o8oo-o83o: Fika

o83o-o93o: Nybesök IVF med läkare Svensson, rum 3

o930-1030: Ultraljud med läkare Johansson, UL-rum

1030-110o: Fika

1100-120o: Äggaspiration med läkare Nilsson

1200-1300: Lunch

1300-1430: Återförande av befruktad ägg med läkare Fredriksson

Jeg ble lettet over at de visste at jeg kom, at jeg slapp å lete etter vaktrommet og legen jeg skulle følge. Og hadde de virkelig laget en individuell plan for meg? Den var tydelig tenkt ut slik at jeg skulle få se mest mulig, i riktig rekkefølge. Jeg hadde hørt at praksis i Sverige var bra, men dette hadde jeg ikke kunnet forestille meg. Plutselig føltes dagen oversiktlig. Timeplanen gjorde at jeg kunne fokusere på her og nå, istedenfor å måtte forholde meg til bekymringer om hvilken lege jeg skulle følge, hvor lenge, når jeg fikk lunsjpause og så videre. Slik uro skaper usikkerhet og ofte sultne, ufokuserte studenter. Og da blir læringsutbyttet mindre.

En erfaring som setter min svenske praksis på førsteplass, begynte med en tavle utenfor et pasientrom på fødeavdelingen. På tavlen sto det: «Barnmorska: Lina. Undersköterska: Anna. Student: Victoria». Jeg oppdaget tavlen noen timer ut i vakten, timer som passiv observatør, selvopptatt og brydd over at jeg ikke kunne bidra. Jeg hadde hatt nok med å ta innover meg synet av og skrikene fra en kvinne i aktive rier på et rom med dempet belysning og regnskogmusikk, og en støttende mann som masserte, motiverte og nærmest gjennomgikk riene selv. Jeg strevde med å forstå resonnementene til leger og jordmødre, hvor i fødselsforløpet kvinnen var, samtidig som jeg romsterte med tanker om at jeg selv kunne havne i denne situasjonen en dag.

Nå ble jeg en del av fortellingen om denne fødselen, om starten på den lille guttens liv

Men her har de altså skrevet meg opp på tavlen utenfor rommet. Jeg er ikke bare «studenten», en observatør til bry som dessverre må være her. Jeg er en del av teamet, avdelingen inkluderer meg. Jeg fulgte jordmoren inn på vaktrommet da barnet var født. Hun skrev et gratulasjonskort fra fødeavdelingen, med tidspunkt for fødselen, vekt og lengde. «Vi som hade glädjen att hjälpa till var barnmorska Lina, undersköterska Anna och läkarstudent Victoria.» Jeg ble overrasket over å bli nevnt. Dette var jo ikke skrift på en tavle som kunne viskes bort. Nå ble jeg en del av fortellingen om denne fødselen, om starten på den lille guttens liv.

Mye er bra i norsk praksis. Mye kan vi også lære av svenskene. Vi kan gjøre livet lettere for både lege og lærling ved å gi studentene en timeplan, et navn, omsorg. Det vil lønne seg i det lange løp å utdanne leger som har blitt tatt på alvor og fått respekt og som slik kan vokse seg store og trygge istedenfor å dempe usikkerhet ved å opptre som sine flyktige rollemodeller fra studietiden. 
Publisert: 18. november 2019. Tidsskr Nor Legeforen. DOI: 10.4045/tidsskr.19.0687

(C) Tidsskrift for Den norske legeforening 2020. Lastet ned fra tidsskriftet.no 